\title{
Serratia ureilytica sp. nov., a novel urea-utilizing species
}

Correspondence

Ranadhir Chakraborty rcnbu2003@yahoo.com
The genus Serratia belongs to the family Enterobacteriaceae of the $\gamma$ subclass of the Proteobacteria. Some members of this genus produce pigments identified as prodigiosin (Hearn et al., 1970; Gerber, 1975). A spore-forming subspecies of Serratia marcescens ( $S$. marcescens subsp. sakuensis) was recently described by Ajithkumar et al. (2003). We have isolated a novel non-pigmented, nonspore-forming strain (isolate $\mathrm{NiVa} 51^{\mathrm{T}}$ ) from water of the River Torsa, West Bengal, India. The Torsa is an international river traversing three countries, China (Tibet), Bhutan and India, before entering Bangladesh. The strain was isolated in February 2001, when the river water had a high free-ammonia nitrogen content $(61 \cdot 2$ p.p.m.) owing to sewage contamination (Bhadra et al., 2003). Strain NiVa $51^{\mathrm{T}}$ was able to hydrolyse urea to ammonia and to utilize urea as a sole nitrogen source for its growth.

During characterization of nickel-resistant copiotrophic bacteria isolated from water from the River Torsa, strain

Published online ahead of print on 27 May 2005 as DOI 10.1099/ ijs.0.63674-0.

The GenBank/EMBL/DDBJ accession number for the 16S rRNA gene sequence of strain NiVa $51^{\top}$ is AJ854062.

Figures showing the growth curve of strain NiVA $51^{\top}$ and phylogenetic trees constructed by using maximum-parsimony, $\mathrm{KITSCH}$ and $\mathrm{FITCH}$ algorithms, and tables detailing the cellular fatty acid composition of strain NiVA $51^{\top}$ and related taxa, and similarity coefficients of members of the family Enterobacteriaceae are available as supplementary material in IJSEM Online.
$\mathrm{NiVa} 51^{\mathrm{T}}$ was recovered on nutrient agar (Himedia) containing $3 \mathrm{mM}$ nickel chloride after incubation at $35^{\circ} \mathrm{C}$ for $24 \mathrm{~h}$. Subcultivation was done on nutrient agar at $35^{\circ} \mathrm{C}$ for 16-18 h. Strain $\mathrm{NiVa} 51^{\mathrm{T}}$ was able to grow on nutrient agar at $10-42^{\circ} \mathrm{C}$, but not at 4 or $45^{\circ} \mathrm{C}$. Growth was also observed at $28^{\circ} \mathrm{C}$ on trypticase soy agar (Difco) after incubation for $16-18 \mathrm{~h}$. Basal medium [ $\left(\mathrm{g} \mathrm{l}^{-1}\right): \mathrm{MgSO}_{4} \cdot 7 \mathrm{H}_{2} \mathrm{O}, 0 \cdot 5$; $\left.\mathrm{KH}_{2} \mathrm{PO}_{4}, 0 \cdot 5 ; \mathrm{KCl}, 0 \cdot 1 ; \mathrm{pH} 6 \cdot 5 \pm 0 \cdot 2\right]$ containing $50 \mathrm{mM}$ glucose and $0.5 \mathrm{mM}$ ammonium sulfate or urea did not support the growth of $\mathrm{NiVa} 51^{\mathrm{T}}$ until supplemented with $0.01 \%$ yeast extract. The same basal medium with similar supplementation was used to determine growth curves. In all growth experiments, a $1 \mathrm{ml}$ aliquot of exponentially grown cells in nutrient broth was centrifuged, washed in sterile $0.86 \mathrm{M} \mathrm{NaCl}$, resuspended in $250 \mu$ l sterile basal medium and inoculated in $20 \mathrm{ml}$ medium contained in $250 \mathrm{ml}$ Erlenmeyer flasks. Cells inoculated in the same medium, but devoid of urea or ammonium sulfate, served as a negative control. Cultures were grown at $35^{\circ} \mathrm{C}$ with shaking. A UV-Vis spectrophotometer (Shimadzu) and a digital $\mathrm{pH}$ meter (Systronics) were used to determine $\mathrm{OD}_{560}$ and the $\mathrm{pH}$ of the culture medium, respectively, at regular intervals. Generation times, calculated from the growth curves (see Supplementary Fig. S1 in IJSEM Online) obtained from the culture media containing urea and ammonium sulfate as a sole nitrogen source, were $120 \pm 2$ and $90 \pm$ $0.2 \mathrm{~min}$, respectively. For estimation of free-ammonia 'nitrogen', generated in the medium containing urea, a $10 \mathrm{ml}$ aliquot of growing culture (withdrawn at regular 
intervals) was filtered through a bacterial-filter membrane (diameter $0.45 \mu \mathrm{m}$ ) and then diluted with ammonia-free distilled water. Quantification of free ammonia was done by following standard techniques (APHA, 1985; Manivasakam, 1980). One of the two control sets contained all the chemical ingredients, including urea, without bacterial cells and the other contained heat-killed cells $\left(100^{\circ} \mathrm{C}\right.$ for $\left.15 \mathrm{~min}\right)$. In the active culture medium containing $0.5 \mathrm{mM}$ urea as sole nitrogen source and at an initial cell density of $3 \times 10^{8}$ cells $\mathrm{ml}^{-1}$, the rate of free-ammonia 'nitrogen' released into the culture medium in the first $2 \mathrm{~h}$ incubation was 0.6 p.p.m. $\mathrm{h}^{-1}$. This reached a maximum rate of $1 \cdot 4$ p.p.m. $\mathrm{h}^{-1}$ after $6-10 \mathrm{~h}$ incubation.

Gram staining was performed following the method of Gerhardt et al. (1994). Cell morphology was observed under a phase-contrast microscope (Olympus, model M021) at $\times 1000$, with cells grown for $16 \mathrm{~h}$ at $35^{\circ} \mathrm{C}$ on nutrient agar. The $16 \mathrm{~S}$ rRNA gene was amplified, cloned and sequenced as described by Carr et al. (2003). The sequence obtained was compared with those in GenBank by using the BLAST N program (Altschul et al., 1997). After multiple alignments of the data using the CLUSTAL X program (Thompson et al., 1997), phylogenetic analysis was performed by using the software package PHYLIP 3.6c (Felsenstein, 2002) according to three different methods [neighbour joining (Saitou \& Nei, 1987), maximum parsimony (Felsenstein, 1983) and maximum likelihood (Yang, 1997)]. For the purpose of neighbour-joining, $\mathrm{KITSCH}$ and FITCH analyses, distances were calculated by using both two-parameter (Kimura, 1980 ) and one-parameter (Jukes \& Cantor, 1969) models in DNADIST. The 16S rRNA gene sequence of Plesiomonas shigelloides (the most closely related species in the family Enterobacteriaceae; Brenner, 1992) was used to root all trees.
To determine the confidence values for individual branches, 100 bootstrap replications were done for each generated tree by using SEQBOOT and CONSENSE from the PHYLIP package. Phylogenetic trees obtained by the maximum-likelihood method showed that strain NiVa $51^{\mathrm{T}}$ branched deeply with the Serratia cluster consisting of $S$. marcescens, Serratia rubidaea and Serratia odorifera (Fig. 1). Similar patterns of branching were noted in trees derived from maximumparsimony, KITSCH and FITCH analysis (see Supplementary Fig. S2 in IJSEM Online). Sequence similarity, based on pairwise sequence comparisons, was investigated by using complete 16S rRNA gene sequences. The 16S rRNA gene sequence of strain $\mathrm{NiVa} 51^{\mathrm{T}}$ showed $96-97 \%$ similarity to many species of the genus Serratia, and $98 \cdot 30-98 \cdot 35 \%$ similarity to $S$. marcescens subsp. sakuensis and S. marcescens subsp. marcescens.

Analysis of non-polar and hydroxy fatty acids was performed following techniques described by Pandey et al. (2002). The fatty acid profile of strain $\mathrm{NiVa} 51^{\mathrm{T}}$ consisted of $12: 0(1 \cdot 4 \%), 12: 02-\mathrm{OH}(0 \cdot 28 \%)$, an unknown fatty acid with equivalent length of $13.957(0.97 \%), 14: 0(6 \cdot 28 \%)$, an unknown fatty acid with equivalent length of 14.502 $(0 \cdot 85 \%), \quad 14: 0 \quad 2-\mathrm{OH}(2 \cdot 21 \%), 15: 0 \quad(0 \cdot 29 \%), 16: 0$ $(31 \cdot 01 \%), 17: 0$ cyclo $(2 \cdot 69 \%), 17: 0(0 \cdot 35 \%), 18: 1 \omega 7 c$ (17.89\%), 18:0 (0.46\%), 19:0 cyclo $\omega 8 c(0 \cdot 25 \%)$, summed feature 2 (comprising 12:0 alde and 14:0 3-OH/ $16: 1$ iso I) $(8 \cdot 01 \%)$ and summed feature 3 (comprising $16: 1 \omega 7 c / 15$ iso $2-\mathrm{OH})(27 \cdot 07 \%)$. The fatty acid profile of strain $\mathrm{NiVa} 51^{\mathrm{T}}$ was compared with those of other members of the same Serratia cluster (S. marcescens, S. rubidaea and S. odorifera) (see Supplementary Table S1 in IJSEM Online), and was found to have a maximum similarity index of 0.747 with $S$. marcescens GC subgroup B.

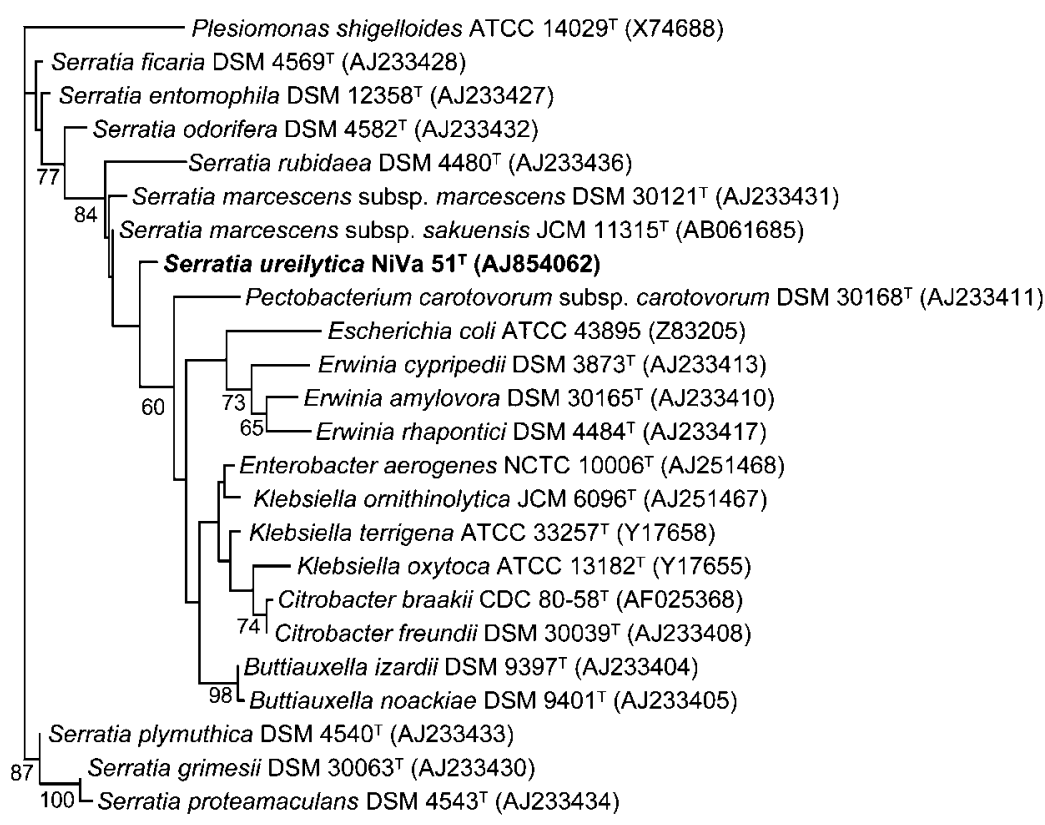

$\overline{1 \%}$
Fig. 1. Phylogenetic position of strain NiVa $51^{\top}$ among related bacteria. The tree was produced by using the maximum-likelihood algorithm and was calculated by using 1430 bases of the 16S rRNA gene sequence. Plesiomonas shigelloides was used as the outgroup. Bootstrap values for 100 replications are given at branch nodes (only values of 60 and above are given). Bar, single substitutions per $100 \mathrm{nt}$. 
For determination of the $\mathrm{G}+\mathrm{C}$ content, DNA was hydrolysed with P1 nuclease, de-phosphorylated with bovine alkaline phosphatase and analysed via HPLC following techniques described by Mesbah et al. (1989). The DNA G + C content of strain $\mathrm{NiVa} 51^{\mathrm{T}}$ was $60 \mathrm{~mol} \%$. This value is higher than that reported for $S$. marcescens subsp. sakuensis $(58 \mathrm{~mol} \%$; Ajithkumar et al., 2003), but close to that for S. marcescens (57.5-60\%; Grimont \& Grimont, 1992).

Results of the physiological characterization are given in the species description below and in Table 1, and were determined with the methods described by Holt et al. (1994) and Ajithkumar et al. (2003). Strain NiVa $51^{\mathrm{T}}$ yielded a maximum similarity coefficient $\left(S_{\mathrm{SM}} ; 0 \cdot 87\right)$ to $S$. marcescens (see Supplementary Table S2 in IJSEM Online).

In order to confirm the phylogenetic conclusions, levels of DNA-DNA relatedness were studied by using the dotblot hybridization method with a DIG DNA Labelling and Detection kit (Roche Diagnostics). The percentage hybridization was quantified by using Molecular Analyst software (Bio-Rad). A probe was prepared from genomic DNA of strain $\mathrm{NiVa} 51^{\mathrm{T}}$ and approximately 1000 -fold of the same was used in hybridizing against frames of three to five target DNAs taken in triplicate quantities on a positively charged nylon membrane. Hybridization was performed at $65^{\circ} \mathrm{C}$ and the membrane was washed under high-stringency conditions. NiVa $51^{\mathrm{T}}$ exhibited a relatively low level of DNA-DNA hybridization with $S$. marcescens subsp. marcescens $(43 \cdot 7 \%)$, S. odorifera $(29 \cdot 2 \%)$, S. rubidaea $(27 \%)$, Pectobacterium carotovorum subsp. carotovorum (21.7\%), Erwinia amylovora (20\%), Citrobacter freundii (19\%) and Enterobacter aerogenes $(18 \cdot 3 \%)$. This indicated strongly that the new isolate represents a novel species of the genus Serratia, according to the criteria used for differentiation of bacterial species (Wayne et al., 1987).

From the phenotypic, chemotaxonomic and phylogenetic results presented here, we can conclude that strain $\mathrm{NiVa}$ $51^{\mathrm{T}}$ forms a separate group within the genus Serratia. The novel species can be differentiated from S. marcescens subsp. marcescens based on phenotypic characteristics, such as pigment production, methyl red test, caseinase, urease, arginine dihydrolase, and growth in the presence of adonitol, xylose, oxalate, DL-threonine and L-tryptophan as sole carbon source. Proportions of the fatty acids 17:0 cyclo and 19: 0 cyclo $\omega 8 c$ in NiVa $51^{\mathrm{T}}$ were approximately four to five times lower than in S. marcescens. $16 \mathrm{~S}$ rRNA gene sequence similarity between $S$. marcescens subsp. marcescens and strain $\mathrm{NiVa} 51^{\mathrm{T}}$ was $98 \cdot 3 \%$ and DNA-DNA relatedness was $43 \cdot 7 \%$. The unique urea-utilizing characteristic of strain NiVa $51^{\mathrm{T}}$ therefore supports its classification as a novel species of Serratia, for which the name Serratia ureilytica sp. nov. is proposed.

\section{Description of Serratia ureilytica sp. nov.}

Serratia ureilytica [u.re.i.ly'ti.ca. N.L. n. urea -ae urea; N.L. adj. lyticus -a -um (from Gr. adj. lutikos) dissolving; N.L. fem. adj. ureilytica urea-dissolving].
Table 1. Biochemical and physiological characteristics of strain NiVa $51^{\top}$ and related taxa

Taxa: 1, NiVa $51^{\mathrm{T}}$; 2, S. marcescens subsp. marcescens LMG $2792^{\mathrm{T}}$; 3, S. marcescens subsp. sakuensis JCM $11315^{\mathrm{T}} ; 4$, Serratia odorifera MTCC495; 5, Serratia rubidaea. All were oxidase-negative, catalasepositive, rod-shaped and motile and could grow in the presence of $1.4 \mathrm{M} \mathrm{NaCl}$; none was able to produce indole, amylase or $\mathrm{H}_{2} \mathrm{~S}$. All strains were positive for the Voges-Proskauer reaction, aesculin hydrolysis, lysine and ornithine decarboxylase, Simmons' citrate and nitrate reduction. All could utilize acetate, succinate, Larginine and L-histidine as sole carbon source and could produce acids from glucose and sucrose. Characteristics that distinguish strain NiVa $51^{\mathrm{T}}$ from $S$. marcescens subsp. marcescens are indicated by an asterisk $\left(^{\star}\right) .+$, Positive; - , negative; NA, data not available; $\mathrm{ND}$, not done.

\begin{tabular}{|c|c|c|c|c|c|}
\hline Characteristic & 1 & 2 & $3 \dagger$ & 4 & $5 \ddagger$ \\
\hline Spore & - & - & $+($ round $)$ & - & - \\
\hline Pigment $^{*}$ & - & + & - & - & - \\
\hline Methyl red* & + & - & - & + & - \\
\hline Caseinase $^{*}$ & + & - & + & - & - \\
\hline Urease $^{*}$ & + & - & - & - & - \\
\hline Lipase (Tween 80) & + & + & + & - & + \\
\hline Arginine dihydrolase $^{*}$ & + & - & - & - & - \\
\hline \multicolumn{6}{|l|}{ Acid production from: } \\
\hline Adonitol $^{*}$ & + & - & NA & - & + \\
\hline Lactose & - & - & - & + & + \\
\hline Sorbitol & + & + & + & + & - \\
\hline Arabinose & - & - & - & + & + \\
\hline Raffinose & - & - & - & $\mathrm{ND}$ & + \\
\hline Rhamnose & - & - & - & + & - \\
\hline Xylose ${ }^{\star}$ & + & - & - & + & + \\
\hline Melibiose $^{\star}$ & + & - & NA & + & + \\
\hline \multicolumn{6}{|c|}{ Utilization of organic acid salts: } \\
\hline Oxalate & + & - & + & $\mathrm{ND}$ & NA \\
\hline Lactate & + & + & - & + & NA \\
\hline \multicolumn{6}{|l|}{ Amino acid utilization: } \\
\hline DL-Serine & + & + & + & $\mathrm{ND}$ & NA \\
\hline L-Ornithine & + & + & - & ND & - \\
\hline DL-Alanine & + & + & + & + & - \\
\hline L-Proline & + & + & NA & ND & NA \\
\hline DL-Threonine ${ }^{\star}$ & + & - & NA & - & NA \\
\hline DL-Phenylalanine & + & + & NA & $\mathrm{ND}$ & - \\
\hline L-Hydroxyproline & + & + & - & + & NA \\
\hline L-Tryptophan* & - & + & NA & + & NA \\
\hline
\end{tabular}

$\dagger$ Data taken from Ajithkumar et al. (2003).

‡Data taken from Grimont \& Grimont (1992).

Cells are facultatively aerobic, Gram-negative, motile, nonfluorescent, non-pigmented, straight rods, $0 \cdot 7-1 \cdot 0 \mu \mathrm{m}$ long and $0 \cdot 8-1 \cdot 0 \mu \mathrm{m}$ wide. Grows between 8 and $43{ }^{\circ} \mathrm{C}$ over a $\mathrm{pH}$ range of 5-11 in nutrient broth media, and can tolerate up to $1 \cdot 4 \mathrm{M} \mathrm{NaCl}$. Positive for arginine dihydrolase. DNA G $+\mathrm{C}$ content is $60 \mathrm{~mol} \%$ and major cellular fatty acids are 16:0 $(31 \cdot 01 \%$ ), summed feature 3 (comprising $16: 1 \omega 7 c / 15$ 
iso $2-\mathrm{OH})(27 \cdot 07 \%)$ and $18: 1 \omega 7 c(17 \cdot 89 \%)$. Can use urea as a sole nitrogen source for growth. Other biochemical characteristics are given in Table 1 . The isolate has a plasmid of $50 \mathrm{~kb}$ of unknown function and can grow in nutrient agar media containing $40 \mu \mathrm{g}$ ampicillin $\mathrm{ml}^{-1}, 15 \mu \mathrm{g}$ tetracycline $\mathrm{ml}^{-1}$ and $20 \mu \mathrm{g}$ chloramphenicol $\mathrm{ml}^{-1}$.

The type strain, NiVa $51^{\mathrm{T}} \quad\left(=\mathrm{LMG} 22860^{\mathrm{T}}=\mathrm{CCUG}\right.$ $50595^{\mathrm{T}}$ ), was isolated from the River Torsa, northern West Bengal, India.

\section{Acknowledgements}

We are grateful to Claudine Vereecke, BCCM/LMG, Belgium, for providing fatty acid data of several bacteria. Special thanks are due to Professor Peter Kämpfer for help with the species etymology. We are indebted to Dr Chandan Ashis Laha, Department of English, North Bengal University, for help with the English text. Financial support from the Council of Scientific and Industrial Research, India, under sanction no. 9/285(16)/2001-EMR-I for one of the authors (B. B.) is also acknowledged.

\section{References}

Ajithkumar, B., Ajithkumar, V. P., Iriye, R., Doi, Y. \& Sakai, T. (2003). Spore-forming Serratia marcescens subsp. sakuensis subsp. nov., isolated from a domestic wastewater treatment tank. Int J Syst Evol Microbiol 53, 253-258.

Altschul, S. F., Madden, T. L., Schäffer, A. A., Zhang, J., Zhang, Z., Miller, W. \& Lipman, D. J. (1997). Gapped BLAST and PSI-BLAST: a new generation of protein database search programs. Nucleic Acids Res 25, 3389-3402.

APHA (1985). Standard Methods for the Examination of Water and Wastewater, 17th edn. Washington, DC: American Public Health Association.

Bhadra, B., Mukherjee, S., Chakraborty, R. \& Nanda, A. K. (2003). Physico-chemical and bacteriological investigation on the River Torsa of North Bengal. J Environ Biol 24, 125-133.

Brenner, D. J. (1992). Introduction to the family Enterobacteriaceae. In The Prokaryotes: a Handbook on the Biology of Bacteria: Ecophysiology, Isolation, Identification, Applications, vol. 3, pp. 2673-2695. Edited by A. Balows, H. G. Trüper, M. Dworkin, W. Harder \& K. H. Schleifer. Berlin: Springer.

Carr, E. L., Kämpfer, P., Patel, B. K. C., Gürtler, V. \& Seviour, R. J. (2003). Seven novel species of Acinetobacter isolated from activated sludge. Int J Syst Evol Microbiol 53, 953-963.
Felsenstein, J. (1983). Parsimony in systematics: biological and statistical issues. Annu Rev Ecol Syst 14, 313-333.

Felsenstein, J. (2002). PHYLIP (Phylogeny Inference Package) version 3.6c. Seattle: University of Washington.

Gerber, N. N. (1975). Prodigiosin-like pigments. CRC Crit Rev Microbiol 3, 469-485.

Gerhardt, P., Murray, R. G. E., Wood, W. A. \& Krieg, N. R. (editors) (1994). Methods for General and Molecular Bacteriology. Washington, DC: American Society for Microbiology.

Grimont, F. \& Grimont, P. A. D. (1992). The genus Serratia. In The Prokaryotes, vol. 3, 2nd edn, pp. 2822-2848. Edited by A. Balows, H. G. Trüper, M. Dworkin, W. Harder \& K. H. Schleifer. New York: Springer.

Hearn, W. R., Elson, M. K., Williams, R. H. \& Medina-Castro, J. (1970). Prodigiosene [5-(2-pyrryl)-2,2'-dipyrrylmethene] and some substituted prodigiosenes. J Org Chem 35, 142-146.

Holt, J. G., Krieg, N. R., Sneath, P. H. A., Staley, J. T. \& Williams, S. T. (editors) (1994). Bergey's Manual of Determinative Bacteriology, 9th edn. Baltimore: Williams \& Wilkins.

Jukes, T. H. \& Cantor, C. R. (1969). Evolution of protein molecules. In Mammalian Protein Metabolism, pp. 21-132. Edited by H. N. Munro. New York: Academic Press.

Kimura, M. (1980). A simple method for estimating evolutionary rates of base substitutions through comparative studies of nucleotide sequences. J Mol Evol 16, 111-120.

Manivasakam, N. (1980). Physico-Chemical Examination of Water, Sewage and Industrial Effluents, 2nd edn. Meerut, India: Pragati Prakashan.

Mesbah, M., Premachandran, U. \& Whitman, W. B. (1989). Precise measurement of the $\mathrm{G}+\mathrm{C}$ content of deoxyribonucleic acid by high-performance liquid chromatography. Int J Syst Bacteriol 39, 159-167.

Pandey, K. K., Mayilraj, S. \& Chakrabarti, T. (2002). Pseudomonas indica sp. nov., a novel butane-utilizing species. Int $J$ Syst Evol Microbiol 52, 1559-1567.

Saitou, N. \& Nei, M. (1987). The neighbor-joining method: a new method for reconstructing phylogenetic trees. Mol Biol Evol 4, 406-425.

Thompson, J. D., Gibson, T. J., Plewniak, F., Jeanmougin, F. \& Higgins, D. G. (1997). The CLUSTAL_X windows interface: flexible strategies for multiple sequence alignment aided by quality analysis tools. Nucleic Acids Res 25, 4876-4882.

Wayne, L. G., Brenner, D. J., Colwell, R. R. \& 9 other authors (1987). International Committee on Systematic Bacteriology. Report of the ad hoc committee on reconciliation of approaches to bacterial systematics. Int J Syst Bacteriol 37, 463-464.

Yang, Z. (1997). PAML: a program package for phylogenetic analysis by maximum likelihood. Comput Appl Biosci 13, 555-556. 